Article

\title{
Perspective on the Influence of Leadership on Job Satisfaction and Lower Employee Turnover in the Mineral Industry
}

\author{
James K.C. Chen \\ Department of Business Administration, Asia University, Taichung City 41354, Taiwan; kcchen@asia.edu.tw; \\ Tel.: +886-4-23323456 (ext. 1968)
}

Received: 13 June 2020; Accepted: 8 July 2020; Published: 15 July 2020

check for updates

\begin{abstract}
A lower employee turnover rate depends on job satisfaction, working conditions, organizational commitment, and leadership factors. Unfortunately, the employee turnover rate is still higher in the mineral industry than in other industries in China. Although there are many research papers on employee turnover, there is little research investigating leadership factors and their influence on employee turnover. This research paper aims to explore the influence of leadership on job satisfaction and its effect on employee turnover in the mining industry. This paper evaluates those factors through the structural equation model (SEM), including a confirmatory factor analysis (CFA) and a path analysis of the model to test the hypotheses. The results of a survey with 368 respondents indicated that the influence of good leadership had positive effects on both job satisfaction and employee turnover, while fair working conditions had positive mediation effects on both leadership and job satisfaction. Organizational commitment had strong effects on employee turnover (estimate values $\beta=0.572, p<0.001)$. However, organizational commitment was not a qualified mediator with both leadership and employee turnover $(\beta=0.312, p<0.001)$. Consequently, the working conditions variable in the work environment was an important independent variable and also one of the key factors for job satisfaction. The higher estimate value $(\beta=0.541, p<0.001)$ of leadership to employee turnover means that it indicated good leadership was a key factor in lowering employee turnover. The results of this study will offer the mining industry a future reference for sustainability and for the field of academic research in the future.
\end{abstract}

Keywords: employee turnover (ET); work conditions (WC); organizational commitment (OC); leadership (L); job satisfaction (JS); mining industry

\section{Introduction}

The mining industry is an important sector of economy development which provides raw materials needed to produce items that impact the national sustainable economic growth [1-3]. Researchers argue that companies in the mining industry in highly developed countries will face key human resource challenges-such as replacing retirees, retention of key talent, increased talent pool training and development, and maintaining employee motivation—over the next few years [1,4]. Furthermore, the mining industry will continue to be a main support to the economy for China [1]. Few studies have concentrated on the mining industry, as it relates to employee turnover. A mining organization's key to success is its human resource function, and if the company can manage their employees, they can achieve their organizational goals, and thus significantly contribute to the growth of the national economy and employment opportunities [1,4]. The industry provides direct employment to over 40 million people which make the employees the industry's most important stakeholders in the world [5]. Chamber of Minerals and Energy (CME) stated that the mining industry has contributed 
to more than 300,000 indirect jobs in the manufacture of downstream products [6]. The CME also reported that the largest mining industry in the world, which is in Western Australia, contributes significant government royalties and provides direct employment to around 70,000 people and indirect employment to around 150,000 [7]. Whereas South Africa, the next biggest producer in the mining sector, is expected to continue its decline in employment to 2025 [7]. The largest mining company in Mongolia, Oyu Tolgoi, who represents $93.5 \%$ of the workforce at the end of 2019, is one of the top 50 mining companies in the world. Many people are directly or indirectly working in the mining industry, including mineral artisans, in Mongolia. Dickie and Dwyer [4] pointed out that mining organizations operate with finite resources, often in remote locations, that require specialized skills, with a high capital intensity. Accordingly, the employee turnover rate is higher than in comparison to other industries [7]. The employee turnover issue is related to human resource (HR) management and the practice of human resources in the mining industry. The Mongolian mining industry was an empirical case in this paper.

Several industries in developed countries are experiencing labor shortages, a particularly critical problem in the mining industry [8]. In the mining industry, when an employee leaves his or her work, or when there is high employee turnover, there are a variety of reasons, such as those related to the individual's life situation or another job opportunity. Particularly, an alternative job opportunity is one important factor in defining the employee turnover issue in this sector. This study significantly pointed out that in Australia, there are few research organizations conducting surveys like the Australian Human Resources Institute (AHRI). The AHRI survey results included the mining industry, with most of the respondents answering that if they found a new career opportunity, they would leave their current work [7].

In contrast, new career opportunities are very limited in Mongolia. In the mining sector, there is a lack of career progression, and job opportunities represent only fifty percent of the respondents [9]. This study utilized the Mongolian mining industry for the empirical case study as to why it offers most people jobs in Mongolia. In addition, managers consistently found ways to lead their employees effectively, which increased company profits. In this regard, the Price Waterhouse Coopers (PWC) survey, outlined in 2015, stated that to be a successful workplace, having a health and well-being program decreased employee turnover by an average of $10-25 \%$ [10].

In general, most of the empirical studies on employee turnover were conducted over the world, mainly in the US, Canada, UK, and Australia [11,12]. Numerous studies have been done on mining companies in the past, such as those conducted by Kuranchie-Mensah and Tawiah [9]; however, very few studies have focused on the Mongolian mining industry. Moreover, there are prior studies and a global survey conducted by the International Institute for Environment and Development (IIED) and the World Business Council for Sustainable Development (WBCSD) [5,13]; with employment in the South American mining sector forecasted to 2025. Recent scholars, including Dickie and Dwyer [4], Zwick [14], AHRI, Kuranchie-Mensah and Tawiah [9], paid attention to safe and healthy working conditions, with opportunities for training and career development in mining and sustainability. Consequently, the employee turnover is higher than in other industries, and how to achieve a lower employee turnover rate is an issue to be faced [14-18].

The modern mining work environment requires a higher level of productivity with longer working hours and a tougher schedule for the employee. Additionally, the laborer in the mining industry works at a higher danger and in a dirtier environment, the Australian Mines and Metals Association (AMMA) noted in its report [19]. The above summary of the literature review is that working environment, working conditions, organization commitment, and job satisfaction impact employee turnover in the mining industry. The purpose of this paper is to investigate employee turnover through working conditions (WC), organizational commitment (OC), leadership (L), and job satisfaction (JS) in the strategy and practices of human resources (HR) of the most technologically advanced in the mining industry by using empirical data. The survey questionnaire for this study was created using the influencing factors associated with employee turnover, and the data were gathered 
from 368 employees in the largest mining companies in Mongolia. Due to the nature of the data from the survey questionnaire, multivariate regression analysis (MRA) was employed to analyze the data.

\section{Theoretical Background and Hypotheses Development}

This section consists of the theoretical framework, the literature review of influential factors such as work conditions, organizational commitment, leadership, job satisfaction and employee turnover, and, thus, the literature reviews are comprehensive, as each factor is considered in this part. In addition, the study mentions the background of the mining industry of Mongolia.

\subsection{Employee Turnover}

The employees in the mining industry prefer convenient, safe and healthy working conditions, with opportunities for training and career development. The study investigates early employment growth and its relationship to firm survival while pointing out that early employment expansion can achieve less employee turnover [20]. IIED and WBCSD [13] defined the above listed conditions can in turn, improve motivation and productivity, lower labor absenteeism or turnover and result in fewer union disputes. Prior employee turnover (ET) research done by Griffeth et al. [21] assumed there was a correlation of factors with employee turnover; thus, the authors included in the meta-analysis of demographic predictors such items as cognitive ability, education, training, marital status, kinship responsibilities, children, race, sex, age and tenure. According to Mowday et al. [22] the definition of employee turnover (ET) is the cessation or termination of membership with the organization by an individual employee. The issue of employee turnover is more related to the person who may have thought to leave his/her job in the organization. Chan et al. [23] pointed out that employee turnover is a serious issue for many organizations and only organizational experts see this as a persistent problem. Moreover, Ton and Huckman [24] argued that academics and organizational managers have paid much attention to employee turnover. Haldorai et al. [25] have used an application of the pull-push-mooring framework which explores the affecting hotel employee's attrition turnover factors. The generalization of employee turnover research is questioned across various situations and populations [21]. The above summary of the literature review on the employee turnover rate with job satisfaction, working conditions, organizational commitment, and leadership factors has a high relationship.

Scholars have stated that social media usage improves job satisfaction and lowers the intention of employee turnover by improving their engagement and their commitment to the organization [26]. The key goal to lower employee turnover is for an employee to decide to stay at their current job for a long period of time. In contrast, when an employee is unable to stay in his/her job in the long term, there will be an increase in the employee turnover rate. Unemployment will negatively influence an employee's personal life and a society's wellbeing [27]. Furthermore, Vandenberg and Nelson [17] argued that a person will probably leave his/her organization for any reason in the near future and it would be related to the employee's personal situation. It is undesirable and unwanted when a company experiences a voluntary attrition rate from several highly valued employees quitting to take other jobs elsewhere and is a much bigger problem than the frequency of corporate layoffs that have been reported [28]. The voluntary attrition rate or employee turnover rate is becoming increasingly important as competition for talent is high and continuously growing. People want to perceive that their skills and experience are valued by the organization [29]. To keep employees in a company, they need to believe they are a valuable part of the organization. To better understand the problem of why employees are leaving, several pertinent measures need to be taken, as organizations are now competing for talent [30]. Taylor [29] suggested that measures such as competitive salaries, comprehensive benefits, incentive programs, and similar initiatives should be executed and will improve the retention of employees. Besides, paying financial incentives can increase an employee's commitment, and satisfaction. Most employee turnover models assume that job dissatisfaction is the primary reason for leaving. There are papers with extensive evidence that support the negative 
relationship between employee turnover and job satisfaction [26,28,30-32]. This research paper included factors which are relevant to employee turnover according to the subsections of literature.

\subsection{Work Conditions}

An important influential factor of employee turnover is work conditions (WC). Working conditions for scholars, researchers, and decision-makers have not been discussed much on the job. Working conditions (WC) refer to the work environment and aspects of an employee's terms and conditions of employment $[33,34]$. It is posited that the work environment of an occupation impacts an employee's satisfaction for life, meaning that people, who are more comfortable in the environment of their occupation also have more satisfaction in their own life. Working conditions also include time management resources and facilities, personal empowerment and opportunities for professional advancement within the company $[35,36]$.

Two dimensions such as environmental conditions and hazards are related to employee turnover as it relates to working conditions in the literature [36]. Environmental conditions range from ordinary to extreme in terms of factors such as heat, humidity, noise, smell, light and dust [33]. Unpleasant environmental conditions have both direct and indirect effects on employee job performance. Hazards are often unavoidable, such as direct or indirect exposure to minor wounds or scalding, flammable materials, electrical hazards, occupational disease, and life-threatening hazards. It is believed that ergonomic deficiencies are the root cause of workplace health hazards and a low level of safety [37]. The mineral industry's environmental conditions still are not so good, as well as the hazards, which have a positive relationship with a high employee turnover rate. How the solution to these problems are found is a key issue for the mining sector. Many business sectors, such as hospitality and tourism, have relied on the application of adoption through rapid advances in automation equipment, robotics, and artificial intelligence (AI) technologies [38], and the emergence of the industry 4.0 concept, or the fourth industrial revolution, which are expected to prompt significant changes to those business sectors [39]. The advent of machines powered by artificial intelligence (AI) and robotic technologies have already strongly influenced the hospitality industry [40]. The mining industry must learn how to adopt $\mathrm{AI}$ and robotic technologies in their sector and improve working conditions for the employee. As described in the above literature, this research created the following hypotheses:

Hypothesis 1. Working conditions (WC) mediate the influence of leadership (L) on job satisfaction(JS).

Hypothesis 2. Working conditions (WC) positively influence lower employee turnover (ET).

\subsection{Job Satisfaction}

Herzberg et al. [41] framed the concept that an individual draws satisfaction from different aspects of her/his own job. Maslow's [42] hierarchy of needs and Herzberg's [43] motivation theory, where the presence of motivators create job satisfaction (JS), are distinguished from hygiene factors, which are the absence of what produces job dissatisfaction. Process theories of motivation explain motivation as a thought process that influences behavior. Job satisfaction (JS) is the degree to which one likes his or her job [44]. Thompson [45] identified job factors such as achievement, recognition, responsibility, the possibility of advancement, and salary significantly related to job satisfaction. According to the literature of employee turnover research, it was found that job satisfaction and organizational commitment were two of the best predictors of employee turnover [21]. Additionally, Sell and Cleal [46] proved that an employee's wage is one essential factor that relates to job satisfaction. Specifically, wages and benefits are universally important. Occupational health and safety are one of the employee-related issues that are specifically significant for the mining and mineral industry AMMA [19]. Previously, in 2001, the Minerals Council of Australia (MCA) reported that there had been one fatality per year in every 1000 people in South African gold mines in the period of 1990-2000. 
A recent study Chen, and Zorigt [36] evaluated that job dissatisfaction is the number one reason for turnover through employee turnover models and, therefore, there is an extensive body of work that supports the negative relationship between employee turnover and job satisfaction [15]. Spector [44] found more modest correlations with job satisfaction, such as salary, age, job position level, absenteeism, and turnover.

\subsection{Leadership}

Over the past 30 years, leadership (L) has become one of the most studied areas of organizational development [47-50]. Both private and public organizations have researched this area. It has been studied more in the past three decades, and is still an essential field of study for both private and public organizations [47,49-51]. In leadership (L) theory, most scholars consider both transformational and transactional leadership. At first, Burns originated the concept of transformational leaders as those leaders who recognize and exploit an existing need or demand of a potential follower [49]. Bass and Avolio [51] identified two transactional leadership components that include contingent reward and active management-by-exception. According to Bass and Riggio [47] the leader obtained agreement on work requirements with the follower, in exchange for promised rewards upon completing the assignment satisfactorily. Part of the theoretical framework of this study was based on Bass and Avolio's [51] model of full-range leadership, and based on the refined-transformational leadership component which includes idealized influence, inspirational motivation, intellectual stimulation, and individualized consideration. According to Bass and Avolio [51] transformational leaders should be focused beyond immediate needs, focusing instead on greater essential requirements, but when compared to transactional leaders, they are fixated on resource allocation and exchange. A leader's essential role is to motivate his/her employees in every area of job performance. The motivation behind human behavior began with Maslow's [42] hierarchy of needs, covering physiological, safety, social esteem, and self-actualization. An Institute of Management and Administration survey in 2006, involving 1264 employers, revealed a decrease in job satisfaction when there was an increase in high anticipation of good employee leadership. In one mining study, Dickie and Dwyer [4] pointed out that the mining industry has experienced aging of their workforce, with a work flow that effects knowledge management, supervisor training, leadership identification, etc. As stated above in the leadership literature, this paper has created three hypotheses:

Hypothesis 3. Leadership (L) has a positive influence on job satisfaction (JS).

Hypothesis 4. Working conditions (WC) have a positive influence on job satisfaction (JS).

Hypothesis 5. Leadership (L) has a positively influence to lower employee turnover (ET).

\subsection{Organizational Commitment}

Organizational commitment (OC) by the employee has been detailed as the degree of an individual's identification with, and devotion to, a specific organization, including value commitment, effort commitment, and retention commitment [33,52]. When an employee receives a positive commitment from his/her organization then he or she should be ready to achieve the organization's goals. This term is defined as the relative strength of an individual's identification with and their involvement in a particular organization [22,53]. The antecedents of organizational commitment can be divided into three broad categories: organizational factors, personal factors, and work experiences [22,54-56]. In the leadership literature, a number of authors have referred to effective leadership as being characterized as empowering which, in turn, would be expected to enhance the employee's organizational commitment and effectiveness $[57,58]$. 
The concept of organizational commitment embraces the following employee factors: (a) a desire to strive to the fullest in order to represent an organization; (b) a desire to remain with an organization; (c) feelings of belonging and loyalty to an organization; (d) acceptance of major organizational goals and values; and (e) a positive evaluation of an organization. The organizational commitment that includes these items is measured by an organizational commitment questionnaire [22] for the independent and mediation variables in this study. This was only to measure employee turnover. As the above literature states about $\mathrm{OC}$ for an organization, this paper has created the following hypotheses:

Hypothesis 6. Organizational commitment (OC) positively influences lowering employee turnover (ET).

Hypothesis 7. Organizational commitment (OC) mediates the influence of leadership $(L)$ on lowering employee turnover (ET).

\subsection{Background on the Mining Industry of Mongolia}

This industry has defended itself mainly on the basis of its contribution to economic development. However, the Mongolian mining industry has created much employment already. Over the past 25 years, this country has transformed into a vibrant democracy, with triple the level of gross domestic product (GDP) per capita, with increasing school enrolments, and dramatic declines in maternal mortality and child mortality [59]. Additionally, with vast agricultural and mineral resources and an increasingly educated population, Mongolia's long-term development prospects are bright. Mongolia has large reserves of coal, copper, and fluorspar [60]. Mineral deposits with copper, gold, molybdenum, tin, and tungsten are common in Mongolia [60]. More recently, the Mongolian government stated that the mining companies' exploration included coal, copper, and copper concentrate with crude oil, iron ore, flour spare, and flour spare concentrate, and molybdenum concentrate with salt mining, zinc concentrate, and metal steel and metal foundries [61]. The current mining situation, including the GDP from the mining industry and wages in manufacturing, were considered for this study. Mining has been one of most important industries for the Mongolian economy since the 2000s.

\section{Methodology}

\subsection{Research Design and Sampling}

This study used a quantitative approach to measure the relationship between working conditions, job satisfaction, organizational commitment, leadership and employee turnover. This study used a structured questionnaire for primary data collection. The data were collected from the employees who work in the mining companies of Mongolia. The total sample size was 368 employees. Researchers have collected the questionnaires through traditional paper questionnaires and online. A total of 27 items with a five-point Likert scale of, 1-strongly disagree to 5-strongly agree, were used to measure all the variables in the study.

\subsection{Data Analysis Procedure}

Questionnaires developed from prior research were used to measure working conditions (WC), organizational commitment (OC), leadership (L) and lower employee turnover (ET) and were based on subjective evaluation involving self-reported measures. The questionnaire designed for this research was comprised of two parts. The first part of the questionnaire included demographic information such as gender, age, education, salary, company name, job position, years worked in a mining company and total job experience. The second part had 5 sections, such as WC (4 items), OC (5 items), L ( 9 items), JS (4 items) and ET (5 items). The survey questionnaire, with these 27 items, was developed to obtain responses from employees in the Mongolian mining companies. The respondents in this research were engineers, managers, and employees from mining companies and the healthcare industry of Mongolia. In an attempt to not disrupt business operations and to ensure that the respondents would receive 
documents in the shortest possible time frame, questionnaires were distributed either through the online web system or by asking the respondent to answer the questionnaire face-to-face.

\subsection{Exploratory Factor Analysis}

Exploratory factor analysis (EFA) is an important tool for organizational researchers. It can be useful for refining measures, evaluating construct validity, and in some cases, testing hypotheses. The results of both the Kaiser-Meyer-Olkin (KMO) Test and the Bartlett's Test of Sphericity needed to be considered satisfactory before factor analysis could proceed. According to Coakes, Steed and Ong [62], in order to assume factorability, the KMO must be greater than 0.60, and the Bartlett's Test of Sphericity must be large and significant, while the anti-image correlation matrix and communality values must be greater than 0.50 and the eigenvalues must be greater than 1 . According to Hair, Black, Babin, Anderson and Tatham [63], factor loading should be 0.5 or higher, and ideally, 0.7 or higher. From Table 1 of this paper, all the loaded factors are higher than 0.5 , which means this research is highly reliable.

Table 1. Factor analysis, instrument validity and reliability.

\begin{tabular}{|c|c|c|c|c|c|c|c|}
\hline \multirow{2}{*}{ Variables } & \multirow{2}{*}{ Items } & \multirow{2}{*}{$\mathbf{M}$} & \multirow{2}{*}{ SD } & \multirow{2}{*}{$\%$ of Variance } & \multicolumn{2}{|c|}{ Loading } & \multirow{2}{*}{$\begin{array}{c}\text { Cronbach's } \\
\text { Alpha }\end{array}$} \\
\hline & & & & & EFA & CFA & \\
\hline \multirow{4}{*}{ Job satisfaction (JS) } & JS1 & & & & 0.698 & 0.554 & \\
\hline & JS2 & & 1.065 & 13.550 & 0.741 & 0.712 & 0.750 \\
\hline & JS3 & & & & 0.727 & 0.592 & \\
\hline & JS4 & & & & 0.642 & 0.534 & \\
\hline \multirow{5}{*}{ Organizational commitment (OC) } & OC1 & & & & 0.670 & 0.619 & \\
\hline & OC2 & & 0.962 & 14.487 & 0.727 & 0.650 & 0.778 \\
\hline & OC3 & & & & 0.760 & 0.675 & \\
\hline & OC4 & & & & 0.766 & 0.653 & \\
\hline & OC5 & & & & 0.716 & 0.620 & \\
\hline \multirow{9}{*}{ Leadership (L) } & L1 & & & & 0.804 & 0.790 & \\
\hline & $\mathrm{L} 2$ & & & & 0.795 & 0.750 & \\
\hline & L3 & & 1.087 & 14.343 & 0.639 & 0.602 & 0.798 \\
\hline & L4 & & & & 0.754 & 0.695 & \\
\hline & L5 & & & & 0.843 & 0.783 & \\
\hline & L6 & & & & 0.782 & 0.756 & \\
\hline & L7 & & & & 0.809 & 0.758 & \\
\hline & L8 & & & & 0.854 & 0.855 & \\
\hline & L9 & & & & 0.841 & 0.836 & \\
\hline \multirow{4}{*}{ Working conditions (WC) } & WC1 & & & & 0.751 & 0.791 & \\
\hline & WC2 & & 0.965 & 13.290 & 0.742 & 0.514 & 0.752 \\
\hline & WC3 & & & & 0.704 & 0.442 & \\
\hline & WC4 & & & & 0.690 & 0.672 & \\
\hline \multirow{5}{*}{ Lower employee turnover (ET) } & ET1 & & & & 0.816 & 0.748 & \\
\hline & ET2 & & 1.032 & 14.740 & 0.811 & 0.768 & 0.820 \\
\hline & ET3 & & & & 0.617 & 0.495 & \\
\hline & ET4 & & & & 0.852 & 0.829 & \\
\hline & ET5 & & & & 0.796 & 0.734 & \\
\hline \multirow{3}{*}{ Instrument Total } & \multicolumn{3}{|c|}{ Cumulative (\%) } & \multicolumn{2}{|c|}{70.410} & & \\
\hline & \multicolumn{3}{|c|}{$\mathrm{KMO}$} & \multicolumn{2}{|c|}{$\begin{array}{l}0.871 \\
0.000\end{array}$} & & 0.813 \\
\hline & \multicolumn{3}{|c|}{$p$-value } & \multicolumn{2}{|c|}{0.000} & & \\
\hline
\end{tabular}

\subsection{Confirmatory Factor Analysis}

In this study, CFA was performed to examine the relationship between the items and their respective latent variables using Analysis of Moment Structures (AMOS) v24 software. 


\subsection{Research Framework}

This study created the research framework model based on literature review and hypothesis. The research framework model is shown in Figure 1.

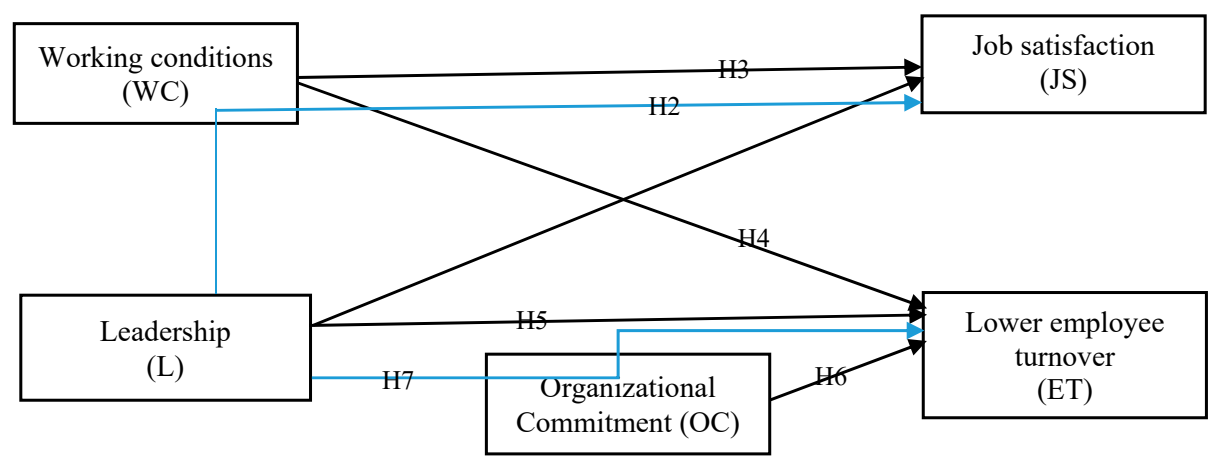

Figure 1. The research framework.

\section{Data Analysis}

\subsection{The Respondent Sampling}

The majority of the respondents were male in this study which composed $64.2 \%$ (94) of the respondents. Most of the respondents were between the ages of 24-29 years old (45.4\%), followed by respondents 30-35 years old (20.9\%). The highest education levels for the respondents were from high school, college, masters, and doctorate degrees. The highest percentage had a bachelor's degree $(54.3 \%)$, followed by a master's (33\%), then Ph.D. (11\%). In terms of job position, most of the respondents were engineers $(153,41.6 \%)$, then mechanics $(66,17.9 \%)$, while various other job positions followed (54, 14.6\%). Most, or 66 respondents (17.93\%), of the respondents were working at Oyu Tolgoi, LLC, followed by Energy Resource LLC with 49 respondents (13.31\%), and the Sharyn Gol coal mine had 34 respondents (9.24\%). Respondents in the category name "other" imply that these are the respondents who work in small-medium mining companies and are artisan miners. Thirty-two percent of the respondents had an income of US $\$ 1401 /$ month and higher, followed by respondents with US $\$ 501-800 /$ month (26.6\%) income. One hundred thirty-eight (37.5\%) of 368 respondents currently worked $1-3$ years in mining, followed by respondents working $4-6$ years $(20.9 \%)$. For total work experience, the highest percentage is $7-11$ years $(17.3 \%)$, followed by $62(17 \%)$ respondents working for less than one year. As a result, most of the respondents worked her/his current position for 1-3 years $(138,37.5 \%)$ while $81(22 \%)$ respondents had worked only one year in their position. Only $12.78 \%(47)$ of the respondents have worked for more than 10 years in their position.

\subsection{Exploratory Factor Analysis}

Exploratory factor analysis (EFA) is an important tool for organizational researchers. As mentioned before, it can be useful for refining measures, evaluating construct validity, and in some cases, testing hypotheses. The result of the Kaiser-Meyer-Olkin (KMO) test was 0.871 . Otherwise, all KMO factors were shown to be greater than 0.60 . The Bartlett's Test of Sphericity must be large and significant, with an anti-image correlation matrix and communality values estimated greater than 0.50 and Eigenvalues greater than 1 . The factor loading the lowest item was 0.617 (ET3), and the highest item (L8) was 0.854 , so the EFA could provide the next analysis for this study (Table 1). A total of 27 measures were used in the data analysis to capture the various latent constructs.

\subsection{Confirmatory Factor Analysis}

In confirmatory factor analysis (CFA), JS4, OC2 and, L2 were removed from the model. The AMOS v24 results indicated that the removal of these nine items would improve the model fit. Goodness of fit 
for each model was evaluated and compared with the suggested criteria by the ratio of chi-square to degrees of freedom $\left(\chi^{2} / \mathrm{df}\right)$, the goodness-of-fit index (GFI), the adjusted goodness-of-fit index (AGFI), the root mean square error of approximation (RMSEA), and the comparative fit index (CFI). The measurement model of CFA in this model shows that the fit index for the structural model indicated a good fit $\left(x^{2}=168.058(\mathrm{df}=109) ; p\right.$-value $=0.000 ;$ RMSEA $\left.=0.38 ; \mathrm{NFI}=0.932 ; \mathrm{CFI}=0.975 ; \mathrm{GFI}=0.948\right)$. Based on this analysis, the confirmatory factor analytic model was accepted (Table 2). In structural equation modeling (SEM), the model refers to a theory that determines a meaningful relationship between variables [55]. Model fit indices provide validation and acceptance for a model. For example, chi-square/degrees of freedom $\left(\chi^{2} / \mathrm{df}\right)$ is an absolute fit index where between 2.0 and 5.0 is acceptable, and less than 2.0 is considered very good [55]. The root mean square error of approximation (RMSEA) is also an absolute fit index and should be $<0.07$. The comparative fit index (CFI) is acceptable at 0.08 while normed-fit-indices (NFI) are acceptable at 0.9 and the good fit index (GFI) must be close to 0.9 (Table 2).

Table 2. CFA goodness-of-fit statistics $(\mathrm{N}=368)$.

\begin{tabular}{cccc}
\hline GOF Index & Good Fit & Acceptable Fit & Structural Model \\
\hline $\mathrm{X}^{2}$ (chi-square) & & & 168.058 \\
$\mathrm{df}($ degrees of freedom) & & & 109 \\
$\mathrm{X}^{2} / \mathrm{df}$ & $<2$ & $2.0-5.0$ & 1.541 \\
Probability & 0.000 & 0.050 & 0.000 \\
NFI & $>0.90$ & $0.85-0.90$ & 0.932 \\
CFI & $>0.90$ & $0.85-0.90$ & 0.975 \\
GFI & $>0.90$ & $0.85-0.90$ & 0.948 \\
TLI & $>0.90$ & $0.85-0.90$ & 0.968 \\
RMSEA & $<0.06$ & $0.06-0.08$ & 0.038 \\
\hline
\end{tabular}

\subsection{Convergent Validity}

To deal with convergent validity, Hair et al. [64] suggested using three common indices to evaluate the measurement model. They are individual item reliability stated in Table 3, composite reliability (CR) and average variance extracted (AVE). In this study, factor loading of the measurement items for each latent variable were significant for convergent validity with the lowest being $0.724>0.7$ (JS), so these results show a high degree of reliability [64] (see Table 3). Secondly, composite reliability (CR) was applied to test the internal consistency of each latent variable. The results of CR were calculated and are shown in Table 3. The CR value of each latent variable is between 0.724 and 0.919 indicating strong composite reliability. Finally, we used the average variance extracted (hereinafter referred to AVE) to measure the degree of the explained variance attributable to the measurement items of these variables. In different terms, AVE is a measure of the error-free variance of a set of items. The results are shown in Table 3. The AVE values ranged from 0.538 to 0.634 . These AVE estimates exceeded the suggested criteria of 0.5 [65].

Table 3. Test of composite reliability and average variance extracted.

\begin{tabular}{ccc}
\hline & CR & AVE \\
\hline Working Conditions & 0.756 & 0.538 \\
Job Satisfaction & 0.724 & 0.597 \\
Organizational Commitment & 0.793 & 0.634 \\
Leadership & 0.919 & 0.559 \\
Lower Employee Turnover & 0.867 & 0.566 \\
Acceptable value & $>0.70$ & $>0.50$ \\
\hline
\end{tabular}




\subsection{Structural Equation Model}

The results of the CFA analysis indicate that each construct of the research model has strong reliability, convergent validity, and discriminant validity. Therefore, it is suitable for the study as an SEM structural model in this section. Structural equation modeling (SEM) was utilized to analyze, firstly, the measurement model and, secondly, to estimate the structural model and test the proposed research hypotheses. As discussed before, SEM is used to test the overall good fit and determine the relationships among variables. As shown in Table 2, the fit index for the structural model indicated an acceptable fit $\left(x^{2}=168.058,(\mathrm{df}=109) ; p\right.$-value $=0.000 ; \mathrm{RMSEA}=0.038 ; \mathrm{NFI}=0.932 ; \mathrm{CFI}=0.975$; GFI $=0.948)$. Among the 7 proposed hypotheses, all paths were supported and Table 4 presents the results of the structural model test.

Table 4. Summary results of hypothesis testing.

\begin{tabular}{|c|c|c|c|c|c|c|}
\hline Hypothesis & Paths & Estimate & S.E. & C.R. & $p$-Value & Result \\
\hline $\mathrm{H} 1$ & Leadership (L) $\rightarrow$ Job Satisfaction (JS) & 0.203 & 0.052 & 3.865 & $* * *$ & Supported \\
\hline $\mathrm{H} 2$ & $\begin{array}{l}\text { Leadership (L) } \rightarrow \text { Working Conditions } \\
(\mathrm{WC}) \rightarrow \text { Job Satisfaction (JS) }\end{array}$ & 0.386 & 0.060 & 6.417 & $* * *$ & Supported \\
\hline $\mathrm{H} 3$ & $\begin{array}{c}\text { Working Conditions (WC) } \rightarrow \text { Job } \\
\text { Satisfaction (JS) }\end{array}$ & 0.362 & 0.085 & 4.262 & $* * *$ & Supported \\
\hline $\mathrm{H} 4$ & $\begin{array}{c}\text { Working Conditions }(\mathrm{WC}) \rightarrow \text { Lower } \\
\text { Employee Turnover }(\mathrm{ET})\end{array}$ & 0.170 & 0.074 & 2.289 & 0.022 & Supported \\
\hline H5 & $\begin{array}{c}\text { Leadership (L) } \rightarrow \text { Lower Employee } \\
\text { Turnover (ET) }\end{array}$ & 0.541 & 0.062 & 8.715 & $* * *$ & Supported \\
\hline $\mathrm{H} 6$ & $\begin{array}{c}\text { Organizational Commitment } \\
(\mathrm{OC}) \rightarrow \text { Lower Employee Turnover (ET) }\end{array}$ & 0.572 & 0.099 & 5.788 & $* * *$ & Supported \\
\hline $\mathrm{H} 7$ & $\begin{array}{c}\text { Leadership (L) } \rightarrow \text { Organization } \\
\text { Commitment }(\mathrm{OC}) \rightarrow \text { Lower Employee } \\
\text { Turnover }(\mathrm{ET})\end{array}$ & 0.312 & 0.074 & 4.213 & $* * *$ & Supported \\
\hline
\end{tabular}

\subsection{Hypotheses Testing}

Using AMOS v24, we tested the structural equation model and the hypothesized causal relationships between the different constructs of the proposed model (Figure 1). This research paper applied the maximum likelihood estimates (MLE) method recommended by performing a path analysis.

From Table 4, the following conclusions are drawn. Leadership has significant influence on job satisfaction which means that good leadership skills can improve work performance and bring job satisfaction for the employee, where Hypothesis 1 was supported (The value is $\beta=0.203, p<0.001$ ). The results response to Linares [14] stated that leadership has positive significance with job satisfaction. Working conditions have a mediation effect on leadership with job satisfaction with positive significant influence on job satisfaction where Hypothesis 2 was supported (The value is $\beta=0.386, p<0.001$ ). Working conditions have a positive significant influence on job satisfaction which means good working conditions can bring a higher job satisfaction level, where Hypothesis 3 was supported (The value is $\beta=0.362, p<0.001$ ). This results were also the response by Zhang et al. [26] who pointed out through social media promotion that a good working environment/culture can enhance job satisfaction for the employee. Working conditions have influenced lower employee turnover where Hypothesis 4 was supported (the value is $\beta=0.170, p<0.022$ ). It is a weak relationship between working conditions and lower employee turnover. These results, according to Gjerløv-Juel et al. [20], show early employment expansion and long-term survival that can be used to monitor the employee turnover factor. Leadership has significance in relation with lower employee turnover where Hypothesis 5 was supported (the value is $\beta=0.541, p<0.001$ ). Organizational commitment has a positive significant influence on lower employee turnover where Hypothesis 6 was supported (the value is 
$\beta=0.572, p<0.001)$. Organizational commitment has a mediation effect on leadership with a positive significant influence on lower employee turnover where Hypothesis 7 was supported (the value is $\beta=0.312, p<0.001$ ). The results show working conditions have a strong mediation effect to enhance job satisfaction in the mining industry, which is why the employee's working conditions at the mining site have an important influence on the employee turnover rate. Working conditions include issues such as working hours, safety problems, air pollution, and the realization that it is a dangerous occupation. A scholar pointed out that knowledge-intensive mining suppliers (KIMS) build innovation, learning and competence into the mining sector [66]. We suggest that the mining company can adopt innovation technology into the operation systems, set up safe working environments, and become a learning organization for the employee. The other mediation variable, organizational commitment, also had a partially strong mediation effect on this study. Organizational commitment includes factors such as salary, keeping the insurance fee amount level, relaxation or break time, and speeding up job position potential.

\subsection{Result of Mediating Analysis}

The Baron and Kenny [67] guidelines were also used when testing the mediation hypotheses. The results of the model test are indicated in Table 4. From this table, the following conclusions are drawn. Although leadership (L) has significant influence on job satisfaction (JS) (Hypothesis is supported) the mediating effect of working conditions (WC) showed more of a relationship with job satisfaction (JS) $(\beta=0.386, p<0.001)$. Therefore, Hypothesis 2 is supported.

Next, we used a mediating analysis to check the mediating effect of organizational commitment (OC). The results of the model test are also indicated in Table 4 . The relationship between leadership (L) and lower employee turnover (ET) was a better relationship $(\beta=0.541, p<0.001)$. However, because of the mediation effect of $\mathrm{OC}$, there was a positive and significant influence $(\beta=0.312, p<0.001)$. Therefore Hypothesis 7 is supported.

\section{Discussion and Conclusions}

The questionnaires, with official letters attached, were distributed to mining companies. This research paper consisted of 368 questionnaires that were gathered from the employees who work in the mining companies of Mongolia. In this study, the questionnaire was composed of two parts of the survey, which were a demographic survey and a survey covering the measurement of variables. In terms of the demographics of this study, $64.2 \%$ of the respondents were male, and this percentage proved that male employees maintained their positions at work at the mining company. It seems that most mining companies are often in remote locations. In this situation, male employees are able to travel and work in this sector, because the women usually stay at home and take care of their children in Mongolia.

The variables measured in the survey are supported by theoretical studies, as well as the conceptual framework. The study attempted to spread the survey questionnaire to all levels of job positions. Note that an occupation's working conditions impact life satisfaction and are highlighted in Table 4. In this study, most of the respondents were engineers $(153=41.6 \%)$. The employees who had a college degree made up 200 (54.3\%) of the respondents participating in this survey questionnaire. Moreover, the Mongolian workforce, especially in the mining field, is becoming stable and almost all of the miners are 30-35 years old. Respondents in this study were from the largest mining companies which are Oyu Talgoi (OT, LLC); Energy Resource, LLC and other small-medium companies such as Bor Undur and Sharyn Gol, both coal mining companies in Mongolia. The research findings of this study are shown in the following section.

\subsection{Research Findings}

A total of 450 questionnaires were distributed for this research and 368 questionnaires were collected $(81.7 \%)$, taking four months to complete. This research examined the relationship of five 
variables which were WC, JS, OC, L and lower employee turnover (ET). The study has been based on the literature associated with employee turnover (ET) and the case chosen was the Mongolian mining industry. The study's results showed that all of the variables significantly influence lower employee turnover in the Mongolian mining industry. All hypotheses were accepted in this study. The question "Do leadership (L) and working conditions (WC) significantly influence job satisfaction in the Mongolian mining industry?" was answered. Moreover, leadership (L) and organizational commitment (OC) are significantly influenced by lower employee turnover (ET). The findings stated that working conditions have a strong mediator effect and had the most significant influence on job satisfaction. Most importantly, the beta coefficient $(\beta=0.386)$ has been shown to be a higher score than the others. The findings illustrated that organizational commitment did not have a strong mediator effect, but also had significant influence on lower employee turnover. The beta coefficient was shown as $\beta=0.312$.

Whereas the mediating role of working conditions (WC) was tested in the relationship between the independent variable leadership (L) and the dependent variable job satisfaction (JS). As for WC, the standardized beta coefficient increased from 0.202 (without mediation control) to 0.386 (with mediation control). Therefore, Hypothesis 2 was accepted. Hypothesis 7 was accepted as to the aspect of the relationship between the independent variable (L) and the dependent variable (ET) when organizational commitment played a mediating role. As for leadership, the standardized beta coefficient decreased from 0.572 (without mediation control) to 0.312 (with mediation control). It is certain that OC played a weak mediating role for the relationship between the independent variable (L) and the dependent variable (ET). In this industry, there needs to be effective leadership to lower employee turnover. If mining companies implement effective leadership and improve working conditions with innovation technology, employee job satisfaction will increase in this sector. Mining companies must improve these variables to keep employees from quitting their jobs.

\subsection{Academic Contribution}

The literature review of prior studies compliments this paper as it relates to the variables, working conditions, organizational commitment, leadership, job satisfaction and employee turnover. In the introduction section, we have referenced that the largest mining industries are facing some issues with human resource management. In addition, this paper is based on research from the world's largest countries that have mining industries, and cited secondary data from global research organizations, because the mining industry research for Mongolia was more of a match than other countries. In this context, this research paper will contribute to lower employee turnover research and HR management studies for the mining industry. In addition, this study gathered empirical data from the mining industries of Mongolia. The theory of a leadership base can be defined from previous studies. The paper drew from the comprehensive research model in order to inspect essential factors that are specifically related to the human resource function, and it has been built only for the mining industry in this case. The current paper really helps to define employee turnover in this industry. According to the research model, researchers can analyze employee job satisfaction and lower employee turnover in all organizations. For example, the model would be effective, and therefore, could be extended with additional constructs. In addition, this paper is significantly focused on all factors. From the findings of this study, leadership had the most significant influence on job satisfaction. Behind this result, effective leadership is needed in the mining company's daily work. The results of the current study indicate a positive relationship between organizational commitment (OC) and working conditions (WC) for all mining employees. This finding was consistent with the previous literature findings, excluding the previous study about Mongolian mining on employee turnover [36]. However, working conditions for Mongolian mining companies are improving year by year, and it is still essential that working conditions improve when considering the employee turnover issue. However, a recent study conducted by Bakotić and Babić [68] stated that there was a positive relationship between WC and JS, while in the present study, WC was a mediating variable, and has shown a very positive effect on job satisfaction. 
Accordingly, the study proved that the most influential factor was working conditions. Whereas, the results showed that OC was significantly higher and more positively correlated with lower employee turnover. Thus, the current result illustrated that $\mathrm{OC}$ was a more significantly mediator to ET. However, leadership was partly influenced by ET, but it was the most influential factor for job satisfaction.

\subsection{Practical Implication}

The Mongolian mining industry has become critical in the worldwide mining industry [36], so human resource management and human resource strategy are more crucial to its success. This empirical study involves both practical and theoretical implications in human resource management in a mining organization. It can be a guide for managers to enhance employee enthusiasm, and keeping the employee motivated and ready for advancement from the quality of leadership. As the essential findings of this study show, the following issues would be a guide for HR mining managers to help them manage their daily work. First, organizational leadership is significantly related to job satisfaction through employees. In addition to leadership, companies and managers should improve in areas such as effective leadership style, safe and healthy working conditions, and employee motivation. The results of this study proved that organizational management needs to provide more commitment in order to maintain stability for the job. Next, better working conditions are still necessary in the mining sector in Mongolia. This country has only a few cities besides the capital, so the process of urbanization is growing slowly. Furthermore, the distribution of the population for socioeconomic development is unable to provide equality for this country. With urban growth in this area, companies such as Oyu Tolgoi, LLC would be able to retain their employees for a long time. Therefore, managers in other mining companies have to be group-orientated and be a relationship-based team. When managers use an effective leadership style, they are able to improve an employee's confidence further. In this manner, employees would be performing well and could share knowledge easily. In addition, a manager's relationship and collaboration should be positively directed to their employee's family.

\subsection{Limitation and Future Research}

The mining industry is one of the leading sectors in terms of employee turnover rate in the work field; however, the results of this present study show different findings than the previous study for working condition factors. The findings indicated how to improve leadership to keep employee turnover rate low in the mining industry of this country. There are not enough specialized studies in human resources in the Mongolian mining sector to explore how an organization's HR functions can effectively contribute to an organization's performance. This study determined that the Mongolian mining sector needs studies which explore issues with its employees in the near future.

Funding: This research was funded by Asia University R\&D office. Project No. "ASIA-107-AUH-04". We thank Asia University R \& D department office for fellowship and full support of this research.

Acknowledgments: The author gives special thanks to the joiner who participated in this study, and DBA graduate students Amy Lkhagvajav and Puujee Altantsetseg who helped with observation and participant recruitment. The author also thanks for the Institute of Innovation \& Circular Economy of Asia University, for professor Tseng comments. Lastly, we appreciate the comments and feedback from the reviewers.

Conflicts of Interest: The author declares no conflict of interest.

\section{References}

1. Fan, S.; Yan, J.; Sha, J. Innovation and economic growth in the mining industry: Evidence from China's listed companies. Resour. Policy 2017, 54, 25-42. [CrossRef]

2. Shen, L.; Muduli, K.; Barve, A. Developing a sustainable development framework in the context of mining industries: AHP approach. Resour. Policy 2015, 46, 15-26. [CrossRef]

3. Wang, Z.; Sun, J. Analysis of interregional industry linkage and economic distance in China: Evidence from the mining industry. Appl. Econ. 2017, 49, 606-617. [CrossRef] 
4. Dickie, C.; Dwyer, J. A 2009 perspective of HR practices in Australian mining. J. Manag. Dev. 2011, 30, 329-343. [CrossRef]

5. Azapagic, A. Developing a framework for sustainable development indicators for the mining and minerals industry. J. Clean. Prod. 2004, 12, 639-662. [CrossRef]

6. CME (Chamber of Minister and Environment). Australia Strategic Management Issues Facing WA in 2007 and Beyond; Chamber of Minerals \& Energy: Perth, Australia, 2006.

7. Australia Human Resources Institute. HR Pulse: Australia Human Resources Institute Pulse Survey, Turnover and Intention. 2018. Available online: https://www.ahri.com.au (accessed on 14 July 2020).

8. Caron, J.; Asselin, H.; Beaudoin, J.M. Attitudes and behaviors of mining sector employers towards the Indigenous workforce. Resour. Policy 2019, 61, 108-117. [CrossRef]

9. Kuranchie-Mensah, E.B.; Tawiah, K.A. Employee motivation and work performance: A comparative study of mining companies in Ghana. J. Ind. Eng. Manag. 2016, 9, 255-309. [CrossRef]

10. PWC. Survey of the Mining Industry; Price Water House Coopers/MMSD: London, UK, 2018; Available online: https://www.pwc.co.uk/industries/mining.html (accessed on 14 July 2020).

11. Maertz, C.P.; Stevens, M.J.; Campion, M.A. A turnover model for the Mexican maquiladoras. J. Vocat. Behav. 2003, 63, 111-135. [CrossRef]

12. Ovadje, F. Exploring turnover among middle managers in a non-western context. Int. J. Bus. Res. 2009, 10, 64-80.

13. IIED; WBCSD. Breaking New Ground: Mining, Minerals and Sustainable Development, Final Report on the Mining, Minerals and Sustainable Development Project (MMSD), International Institute for Environment and Development and World Business Council for Sustainable Development. 2002. Available online: http://www.iied.org/mmsd (accessed on 30 October 2019).

14. Zwick, T. Training older employees: What is effective? Int. J. Manpow. 2013, 36, 136-150. [CrossRef]

15. Mobley, W.H.; Griffeth, R.W.; Hand, H.H.; Meglino, B.M. Review and conceptual analysis of the employee turnover process. Psychol. Bull. 1979, 86, 493-522. [CrossRef]

16. Amponsah-Tawiah, K.; Ntow, M.A.O.; Mensah, J. Occupational health and safety management and turnover intention in the Ghanaian mining sector. Saf. Health Work 2016, 7, 12-17. [CrossRef]

17. Vandenberg, R.J.; Nelson, J.B. Disaggregating the motives underlying turnover intentions: When do intentions predict turnover behavior? Hum. Relat. 1999, 52, 1313-1336. [CrossRef]

18. Linares, P.J.P. Job Satisfaction, Organization Commitment, Occupational Commitment, Turnover intent and Leadership Style of Tissue Bank Employees. Ph.D. Thesis, Capella University, Minneapolis, MN, USA, 2011.

19. AMMA. Activities Report 2008-Voice of Employers in the Resources Sector; Australian Mines \& Metals Association: Melbourne, Australia, 2009.

20. Gjerløv-Juel, P.; Christina Guenther, C. Early employment expansion and long-run survival: Examining employee turnover as a context factor. J. Bus. Ventur. 2019, 34, 80-102. [CrossRef]

21. Griffeth, R.W.; Hom, P.W.; Gaertner, S. A meta-analysis of antecedents and correlates of employee turnover: Update, moderator tests, and research implications for the next millennium. J. Manag. 2000, 26, 463-488. [CrossRef]

22. Mowday, R.T.; Porter, L.W.; Steers, R.M. Employee-Organization Linkages: The Psychology of Commitment, Absenteeism, and Turnover; Academic Press: New York, NY, USA, 1982.

23. Chan, Y.F.B.; Foon, Y.S.; Lim, C.L.; Syuhally, O. An exploratory study on turnover intention among private sector employees. Int. J. Bus. Manag. 2010, 5, 57-64.

24. Ton, Z.; Huckman, R.S. Managing the impact of employee turnover on performance: The role of process conformance. Organ. Sci. 2008, 19, 56-68. [CrossRef]

25. Haldorai, K.; Kim, W.G.; Pillai, S.G.; Park, T.; Balasubramanian, K. Factors affecting hotel employees' attrition and turnover: Application of pull-push-mooring framework. Tour. Manag. 2019, 73, 172-181. [CrossRef]

26. Zhang, X.; Ma, L.; Xu, B.; Xu, F. How social media usage affects employees' job satisfaction and turnover intention: An empirical study in China. Inf. Manag. 2019, 56, 103136. [CrossRef]

27. Gradín, C.; Cantó, O.; del Río, C. Unemployment and spell duration during the Great Recession in the EU. Int. J. Manpow. 2015, 36, 216-235. [CrossRef]

28. Mobley, W.H. Intermediate linkages in the relationships between job satisfaction and employee turnover. J. Appl. Psychol. 1982, 62, 237-240. [CrossRef]

29. Taylor, C.R. Focus on Talent. Mag. Train. Dev. Dec. 2002, 56, 26-31. 
30. Mitchell, T.R.; Holtom, B.C.; Lee, T.W. How to keep your best employees: Developing an effective retention policy. Acad. Manag. Exec. 2001, 15, 96-107. [CrossRef]

31. Locke, E.A. What is job satisfaction? Organ. Behav. Hum. Perform. 1969, 4, 309-336. [CrossRef]

32. Mobley, W.H.; Horner, S.O.; Hollingsworth, A.T. An evaluation of precursors of hospital employee turnover. J. Appl. Psychol. 1978, 63, 408-414. [CrossRef]

33. Lambert, E.G.; Pasupuleti, S.; Cluse-Tolar, T.; Jennings, M.; Baker, D. The impact of work-family conflict on social work and human service worker job satisfaction and organizational commitment: An exploratory study. Adm. Soc. Work 2006, 30, 55-74. [CrossRef]

34. Lambert, E.G.; Hogan, N.L.; Paoline, E.A.; Baker, D.N. The good life: The impact of job satisfaction and occupational stressors on correctional staff life satisfaction an exploratory study. J. Crime Justice 2012, 28, 1-26. [CrossRef]

35. Hirsch, E.; Emerick, S.; Church, K.; Fuller, E. Teacher Working Conditions Are Student Learning Conditions: A Report on the 2006 North Carolina Teacher Working Conditions Survey; Center for Teaching Quality: Hillsborough, NC, USA, 2007.

36. Chen, J.K.C.; Zorigt, D. Managing occupational health and safety in the mining industry. J. Bus. Res. 2013, 60, 2321-2331. [CrossRef]

37. Kahya, E. The effects of job characteristics and working conditions on job performance. Int. J. Ind. Ergon. 2007, 37, 515-523. [CrossRef]

38. Syam, N.; Sharma, A. Waiting for a sales renaissance in the fourth industrial revolution: Machine learning and artificial intelligence in sales research and practice. Ind. Mark. Manag. 2018, 69, 135-146. [CrossRef]

39. Almada-Lobo, F. The Industry 4.0 revolution and the future of manufacturing execution systems (MES). J. Innov. Manag. 2016, 3, 16-21. [CrossRef]

40. Li, J.; Bonn, M.A.; Ye, B.H. Hotel employee's artificial intelligence and robotics awareness and its impact on turnover intention: The moderating roles of perceived organizational support and competitive psychological climate. Tour. Manag. 2019, 73, 172-181. [CrossRef]

41. Herzberg, F.; Mausner, B.; Snyderman, B.B. Motivation Versus Hygiene; Shtogren, I.J., Ed.; American Management Association: New York, NY, USA, 1959.

42. Maslow, A.A. Theory of human motivation. In Skyhooks for Leadership; Shtogren, J.A., Ed.; American Management Association: New York, NY, USA, 1943; pp. 169-171.

43. Herzberg, F. One more time: How do you motivate employees? Harv. Bus. Rev. 1968, 46, 53-62.

44. Spector, P.E. Measurement of human service staff satisfaction: Development of the job satisfaction survey. Am. J. Community Psychol. 1985, 13, 693-713. [CrossRef] [PubMed]

45. Thompson, R.S. The Perception of Servant-Leadership Characteristics and Job Satisfaction in a Church-Related College. Ph.D. Thesis, Indiana State University, Terre Haute, IN, USA, 2002; p. 119.

46. Sell, L.; Cleal, B. Job satisfaction, work environment, and rewards: Motivational theory revisited. Labor 2011, 25, 1-23. [CrossRef]

47. Bass, B.M.; Riggio, R.E. Transformational Leadership, 2rd ed.; Lawrence Erlbaum Associates, Inc.: Mahwah, NJ, USA, 2006.

48. Bass, B.M. The Bass Handbook of Leadership: Theory, Research, and Managerial Applications, 4rd ed.; Free Press: New York, NY, USA, 2008.

49. Burns, J.M. Leadership; Harper \& Row Press: New York, NY, USA, 1978.

50. Scott, W.R.; Davis, G.F. Organizations and Organizing: Rational, Natural, and Open System Perspectives; Pearson Prentice Hall Press: Upper Saddle River, NJ, USA, 2007.

51. Bass, B.M.; Avolio, B.J. Multifactor Leadership Questionnaire, 3rd ed.; Mind Garden, Inc.: Redwood City, CA, USA, 2004.

52. Moss, S.; McFarland, J.; Kijowska, A. Maintaining an open mind to closed individuals: The effect of resource availability and leadership style on the association between openness to experience and organizational commitment. J. Res. Personal. 2007, 41, 259-275. [CrossRef]

53. Dee, J.R.; Henkin, A.B.; Singleton, C.A. Organizational commitment of teachers in urban schools examining the effects of team structures. Urban Educ. 2006, 41, 603-627. [CrossRef]

54. Allen, N.J.; Meyer, J.P. The measurement and antecedents of affective, continuance and normative commitment to the organization. J. Occup. Psychol. 1990, 63, 1-18. [CrossRef] 
55. Allen, N.J.; Meyer, J.P. Affective, continuance, and normative commitment to the organization: An examination of construct validity. J. Vocat. Behav. 1996, 49, 252-276. [CrossRef]

56. Eby, L.T.; Freeman, D.M.; Rush, M.C.; Lance, C.E. Motivational bases of affective organizational commitment: A partial test of an integrative theoretical model. J. Occup. Organ. Psychol. 1999, 72, 463-483. [CrossRef]

57. Conger, J.A.; Kanungo, R.N. The empowerment process: Integrating theory and practice. Acad. Manag. Rev. 1988, 13, 471-482. [CrossRef]

58. Conger, J.A. Charismatic and transformational leadership in organizations: An insider's perspective on these developing streams of research. Leadersh. Q. 1999, 10, 145-179. [CrossRef]

59. The World Bank-Overview. 2016. Available online: http://www.worldbank.org/en/country/mongolia/overvi ew (accessed on 14 July 2020).

60. Wacaster, S. The Mineral Industry of Mongolia. U.S. Department of the Interior U.S. Geological Survey Minerals Yearbook-2012. 2014. Available online: https://s3-us-west-2.amazonaws.com/prd-wret/assets/palla dium/production/mineral-pubs/country/2012/myb3-2012-mg.pdf (accessed on 14 July 2020).

61. National Statistical System of Mongolia. In Proceedings of the EECCA Conference for a Transformative Agenda for Official Statistics, Minsk, Belarus, 6-7 October 2016. Available online: https://unstats.un.org/uns d/nationalaccount/workshops/2016/eecca/Session_1_Mongolia_EN.pdf (accessed on 14 July 2020).

62. Coakes, S.J.; Steed, L.; Ong, C. SPSS Analysis without Anguish Version 16.0 for Windows; John Wiley \& Sons: Hoboken, NJ, USA, 2009.

63. Hair, J.F.; Black, W.C.; Babin, B.J.; Anderson, R.E.; Tatham, R.L. Multivariate Data Analysis; Pearson Prentice Hall: Upper Saddle River, NJ, USA, 2006; Volume 6.

64. Hair, J.; Black, W.C.; Babin, B.J.; Anderson, R.E. Multivariate Data Analysis, 7th ed.; Pearson Education International: Upper Saddle River, NJ, USA, 2010.

65. Fornell, C.; Larcker, D.F. Evaluating structural equation models with unobservable variables and measurement error. J. Mark. Res. 1981, 18, 39-50. [CrossRef]

66. Stubrin, L. Innovation, learning and competence building in the mining industry. The case of knowledge intensive mining suppliers (KIMS) in Chile. Resour. Policy 2017, 54, 167-175. [CrossRef]

67. Baron, R.M.; Kenny, D.A. Moderator-mediator variables distinction in social psychological research: Conceptual, strategic, and statistical considerations. J. Personal. Soc. Psychol. 1986, 51, 1173-1182. [CrossRef]

68. Bakotić, D.; Babić, T. Relationship between working conditions and job satisfaction: The case of Croatian shipbuilding company. Int. J. Bus. Soc. Sci. 2013, 4, 206-213.

(C) 2020 by the author. Licensee MDPI, Basel, Switzerland. This article is an open access article distributed under the terms and conditions of the Creative Commons Attribution (CC BY) license (http://creativecommons.org/licenses/by/4.0/). 